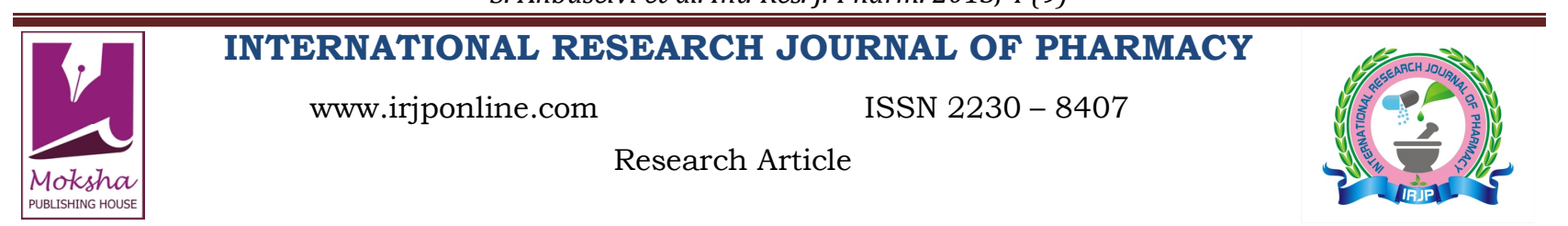

\title{
NUTRITIONAL AND ANTI NUTRITIONAL CONSTITUENTS OF MANIHOT ESCULENTUS AND PLECUTRANTHUS ROTUNDIFOLIUS
}

\author{
S. Anbuselvi*, T. Balamurugan \\ Department of Industrial Biotechnology, Bharath University, Chennai, India \\ *Corresponding Author Email: anbuselvichennai@yahoo.com
}

Article Received on: 20/08/13 Revised on: 01/09/13 Approved for publication: 10/09/13

DOI: $10.7897 / 2230-8407.04919$

IRJP is an official publication of Moksha Publishing House. Website: www.mokshaph.com

(C) All rights reserved.

\section{ABSTRACT}

The nutritional and anti nutritional characterization of two tubers namely Manihot esculenta and Plecutranthus rotundifolius were analyzed. A comparative analysis of nutrients of cassava and Chinese potato were carried out using standard analytical techniques. Results obtained showed high amount of protein, vitamins and low amount of phosphorus were found in leaves of chinese potato. Cassava pulp revealed $65 \mathrm{mg}$ of calcium and $28.6 \mathrm{mg}$ of vitamin A. $29 \mathrm{mg}$ of reducing sugar and $1.8 \mathrm{mg}$ of phosphorus were found in cassava leaves. Anti nutrients were accumulated more in cassava than chinese potato.

Keywords: Anti nutrients, Cassava, Chinese potato, Protein, Phytates

\section{INTRODUCTION}

Food is made up of all nutrients which needed for growth and maintenance of our body. Each nutrient shows specific uses to determine the nutritional status. Balanced diet supplies all nutrients and utilize in adequate amount to maintain optimal health ${ }^{1}$. Anti-nutrients are natural or artificial compounds that interfere with the absorption of nutrients. Phytate and oxalates are easily forms insoluble complexes with copper, iron, zinc and calcium. Tannins chelate metals and reduce the absorption of these nutrients. They inhibit the action of digestive enzymes ${ }^{2}$. Cassava plant ((Manihot esculenta Crantz) is a renewable raw material and it is a major industrial crop in Tamilnadu, India which are rich in antioxidant compounds. Cassava pulp; which is comprised mostly of carbohydrates, protein, crude fat, ash and fiber ${ }^{3}$. It shows a high potential ethanolic fermentation substrate due to its high residual starch level, low ash content and small particle size of the lignocellulosic fibers. Cassava leaves are used to treat hyper tension, headache and pain. Cassava plants are grown in drought condition to improve the economy of the country because of its high anthocyanin content and protein for animal feed ${ }^{4}$. cassava starches are an excellent raw material for food industry to modify the physical properties of many foods for example as gelling, thickening, adhesion, moisture retention, stabilizing, texturizing and anti staling applications ${ }^{5}$. The cassava leaves contain lot of anti nutrients, such as tannins, oxalate, phytate and trypsin inhibitors ${ }^{6}$. Cassava leaves shows high profiling of minerals particularly calcium and trace minerals ${ }^{7}$. Cassava leaves are nutritious but it contains more anti nutrients that cause toxicity ${ }^{8}$. Peoples are economically forced to depend on cassava as a stable food which causes kwashiorkor and endemic goiter'. Plectranthus rotundifolius belongs to lamiaceae family and its sub family is nepetoideae. It is a very rare tuber and originated from African countries. It has been called as "small potato" and "Hausa potato". $P$. rotundifolius plant is also tolerant of high temperatures and rain-fall and prefers well-drained, loose or sady soil and direct sunlight. The plant produces less well in the shade or in dense soil. This potato is commonly harvested in south of Tamil Nadu, India during the month of January-March. Plectranthus rotundifolius are the most frequently citied species for the treatment of burns, wounds, sores, insect bites and allergies biologically active mono and sesquiterpenoids are found in many species of Plectranthus but there are little published data that directly link the presence of specific compounds. The main objective of this research was to investigate the nutritional and anti-nutritional factors of two tubers namely cassava and Chinese potato. It gives knowledge on the nutritional implication on feeding of tubers.

\section{MATERIALS AND METHODS}

Tubers and leaves of Manihot esculenta Crantz and P.rotundifolius were collected from the field during the month of January - March season. The tubers were peeled washed and small portion was used for moisture content by a method described by Onwuka ${ }^{10}$. The remaining portion was subjected to dry in a hot air oven at a temperature of $55^{\circ} \mathrm{C}$ for $24 \mathrm{~h}$. The dried product was further used for crude protein by Lowry et.al ${ }^{10}$. The reducing sugar content in cassava and chinese potato samples were determined quantitatively by using 3' 5 ' dinitrosalicylic acid ${ }^{11}$. Crude fat was determined from these two potatoes by solvent extraction method ${ }^{13}$. Crude fibre was determined by Wende method ${ }^{14}$. Ashing of these tuber flour samples were done according to the methods described by Onwuka ${ }^{10}$ and the digestion were used for mineral element determinations. Phosphorus content was analyzed by spectrophotometry using molybdenum reagent ${ }^{14}$ and Calcium and magnesium were determined by titration method of Udoh ${ }^{15}$. Sodium and potassium contents were analyzed by flame photometry ${ }^{16}$. The cyanogenic glycosides were determined by alkaline pictrate method of $\mathrm{Oke}^{17} .5 \mathrm{~g}$ of dried samples of these tubers and leaves were weighed and dissolved in $50 \mathrm{ml}$ of distilled water in corked conical flasks. The mixtures were allowed to stay overnight and then filtered. To $1 \mathrm{ml}$ of sample was taken in a test tube added 4 $\mathrm{ml}$ of alkaline pictrate and heated in a water bath for 15 minutes. The absorbance of color intensity was measured at $490 \mathrm{~nm}$ in a spectrophotometer compared with standard cyanide solution. Trypsin inhibitor present in tubers was analyzed by methodology of kakade et.al ${ }^{18} .0 .2 \mathrm{~g}$ of sample was taken in a screw cap centrifuge tube dissolved with 0.1 $\mathrm{M}$ phosphate buffer and centrifuged at $5000 \mathrm{rpm}$ for 5 
minutes and filtered through Whatman No 42 filter paper. The volume of the filtrate was made up to $2 \mathrm{ml}$ with phosphate buffer. The test tubes were kept in a water bath at $37^{\circ}$ C. $2 \mathrm{ml}$ of casein was added and incubated for 20 minutes. The reaction was stopped by adding $6 \mathrm{ml}$ of TCA solution. TCA solution served as a blank. The absorbance was read in spectrophotometer at $280 \mathrm{~nm}$ and its concentration can be calculated using standard trypsin. $2 \mathrm{~g}$ of tuber and leaves samples were weighed and soaked in $100 \mathrm{ml}$ of $2 \%$ hydrochloric acid for $3 \mathrm{~h}$ and then filtered through double layer thick filter papers. $50 \mathrm{ml}$ of each filtrate was made up to $150 \mathrm{ml}$ with distilled water. $10 \mathrm{ml}$ of ammonium thiocyanate solution was added as indicator. Each solution was titrated against standard iron chloride solution which contain $0.00195 \mathrm{~g}$ of iron per $\mathrm{ml}$. The end point was slightly brownish yellow ether conthich persists for 5 minutes. The phytate in cassava and Chinese potato were calculated ${ }^{19}$. For tannin analysis $400 \mathrm{mg}$ of samples were placed into two conical flasks. $40 \mathrm{ml}$ of diethyl ether containing $1 \%$ acetic acid was added and centrifuged to remove the pigments. To precipitate was dissolved in $20 \mathrm{ml}$ of $70 \%$ acetone. The flasks were sealed with cotton plug covered with aluminum foil, then kept in a shaker for $2 \mathrm{~h}$. Each content in then flask was filtered through whatman filer paper. $0.5 \mathrm{ml}$ of the filtrate was made up to $1 \mathrm{ml}$ with distilled water. $0.5 \mathrm{ml}$ of folin ciocalteau reagent was added and mixed with $2.5 \mathrm{ml}$ of $20 \%$ sodium carbonate solution was added and mixed. The mixtures were kept for 40 minutes at room temperature. The absorbance was measured by spectrophotometer using tannins as standard Markkar et.al ${ }^{19} .1 \mathrm{~g}$ of sample was dissolved in $190 \mathrm{ml}$ of distilled water. $10 \mathrm{ml}$ of $6 \mathrm{M}$ hydrochloric acid and warmed in water bath at $90^{\circ} \mathrm{C}$ for $4 \mathrm{~h}$ and subjected to centrifugation at a speed of $2000 \mathrm{rpm}$ for 5 minutes. The supernatant was diluted and evaporated. The brown precipitate was filtered off and titrated with ammonia solution until salmon pink color of methyl orange changed to faint yellow. The solutions were heated at $90^{\circ} \mathrm{C}$ and the oxalate was precipitated with $10 \mathrm{ml}$ of $5 \%$ calcium chloride solution. The solutions were allowed to stand overnight then centrifuged. Each precipitate was washed with $25 \%$ sulphuric acid, diluted to $125 \mathrm{ml}$ and warmed at $90^{\circ} \mathrm{C}$. It was titrated against $0.05 \mathrm{M}$ potassium permanganate ${ }^{17}$.

Table 1: Nutritional Composition of Manihot esculenta Crantz and P. rotundifolius

\begin{tabular}{|c|c|c|c|c|c|}
\hline \multicolumn{2}{|c|}{ Nutritional components } & (Manihot esculenta Crantz) & \multicolumn{2}{c|}{ Plectranthus rotundifolius } \\
\hline S. No & & Tuber & Leaves & Tuber & Leaves \\
\hline 1. & Reducing sugar (mg) & 25 & 29 & 26 & 21 \\
\hline 2. & Protein (mg) & 6.8 & 7.0 & 14.6 & 15.8 \\
\hline 3. & Crude fat (\%) & 4.6 & 3.6 & 1.2 & 0.9 \\
\hline 4. & Crude fibre (\%) & 4.0 & 4.6 & 1.6 & 2.1 \\
\hline 5. & Moisture (\%) & 79.5 & 78.6 & 62 & 79 \\
\hline 6 & Phosphorus (mg) & 50 & 73 & 36 & 24 \\
\hline 7. & Calcium (mg) & 65 & 23 & 29 & 36 \\
\hline 8. & Magnesium (mg) & 0.1 & 0.3 & 0.03 & 0.06 \\
\hline 9 & Sodium (mg) & 0.6 & 1.4 & 1.2 & 0.8 \\
\hline 10 & Potassium (mg) & 0.3 & 1.8 & 0.1 & 0.9 \\
\hline 11 & Vitamin A (mg) & 28.6 & 10.3 & 13.6 & 11.5 \\
\hline 12 & Vitamin C (mg) & 0.2 & 1.6 & 10.3 & 14.6 \\
\hline
\end{tabular}

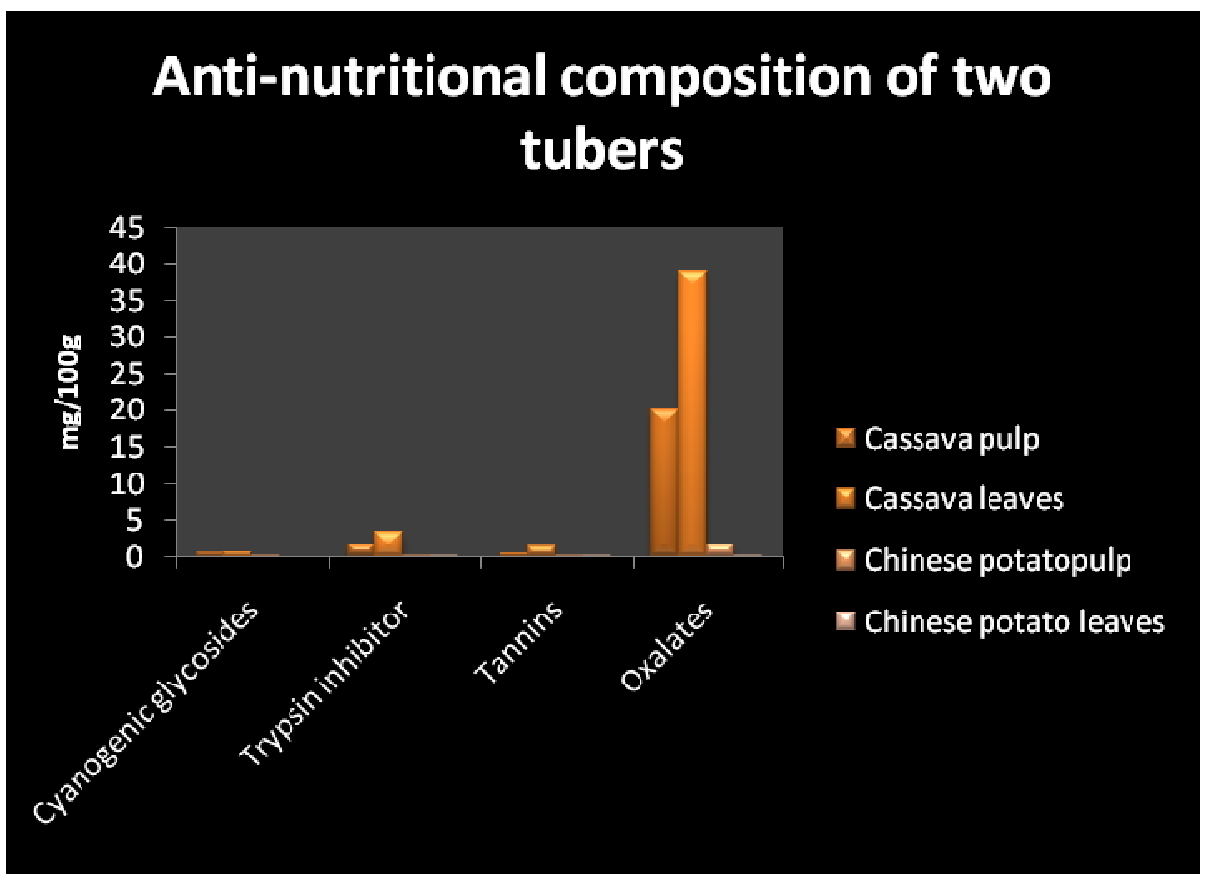

Figure 1: Anti- nutritional Constituents of Cassava and Chinese potato 


\section{RESULTS}

The nutritional constituents of Manihot esculentus and $P$. rotundifolius leaves and tubers were quantitatively assessed and summarized in Table 1. The maximum amount of reducing sugar was observed in tubers of chinese potato (26 $\mathrm{mg}$ ) and cassava leaves $(29 \mathrm{mg})$. The maximum amount of crude fiber was found in tubers of cassava (4.6\%) and chinese potato $(1.1 \mathrm{mg})$ than tubers. Crude fat was found to be significantly present in tuber of cassava pulp (4.6\%) and Chinese potato $(1.2 \%)$. The higher amount of sodium, potassium and phosphorus were observed in cassava leaves when compared with Chinese potato leaves. The minimum amount of vitamin $\mathrm{C}$ and maximum amount of vitamin $\mathrm{A}$ were found in cassava pulp. The anti nutritional constituent such as trypsin inhibitor was found to be higher in leaves of cassava and Chinese potato. The high amount of oxalate and phytate were observed to be $38 \mathrm{mg}$ and $300 \mathrm{mg}$ in cassava leaves. Tannins and cyanogenic glycosides were found to be trace amounts in leaves of Chinese potato (Figure 1).

\section{DISCUSSION}

W Leung (2008) reported on nutritional value of $P$. esculentus in South Africa reported that $81 \%$ of Carbohydrates $13.5 \%$ Crude proteins $4 \%$ ash and $1 \%$ fat $^{20}$. High amount of protein content was observed in $P$. rotundifolius leaves $15.8 \mathrm{mg}$ and $7.0 \mathrm{mg}$ found in cassava leaves. Therefore leaves can be used as animal feed. Manihot esculentus and $P$. rotundifolius leaves showed maximum amount of moisture content. The values obtained were found to be somewhat higher than that reported by Frederick ${ }^{21}$. Calcium content was found to be minimum in cassava leaves of $23 \mathrm{mg}$. This could be due to higher level of oxalic acid and phytates being the major chelators of calcium for biological activities. However some toxic substances can be reduced by cooking and fermentation process. Phytates and oxalates usually forms insoluble salts with zinc, calcium and iron to prevent their utilization.

\section{CONCLUSION}

The nutritional and anti nutritional constituents of two tubers namely cassava and Chinese potato were analyzed in this study. The maximum amounts of nutrients were observed in leaves when compared with tubers of cassava and Chinese potato. The cassava leaves showed high level of cyanogenic glycosides, tannins, oxalates, phytate and trypsin inhibitors. Therefore leaves can be used as animal feed and tubers are used as a substrate for fermentation to yield ethanol.

\section{REFERENCES}

1. Thomas MD. Text book of Biochemistry. $6^{\text {th }}$ ed. Wiley Liss, U.S.A; 2006. p. 1080-1084. PMid: 16919058

2. Beecher GR. Overview of dietary flavanoids. Nutr. J 2003; 10: 32483254 .

3. Eggum BO. The protein quality of cassava leaves. Br. J. Nutr 1970; 24 : 761-768. http://dx.doi.org/10.1079/BJN19700078 PMid:5470778

4. Cooke RD, Marduagwu. The effect of simple processing on the cyanide content of cassava chips. J. Food. Technol 1985; 13: 299-306. http:// dx.doi.org/10.1111/j.1365-2621.1978.tb00807.x

5. Nitayavadhana S, Shrestha P, Rasmussen ML, Lamsel BP, Van Leeuwan J, Khanal SK. Ultrasound improved ethanol fermentation from cassava chips slurry in cassava based ethanol plants, Biosource Technol 2010; 101suppl 8: 2741-2747. http://dx.doi.org/10.1016/j.biortech. 2009.10.075 PMid:19939670

6. Ebuehi OAT, Babalola O, Ahmed S. Phytochemical nutritive and antinutritive composition of cassava tubers and leaves, Nig. Food. J 2005; 23: $40-46$.

7. Awoyinka AF, Abegunde VO, Adewusi SRA. Nutrient content of young cassava leaves and assessment of their acceptance as green vegetable in Nigeria plant foods. Hum. Nutr 1995; 47: 21-28. http://dx.doi.org/ 10.1007/BF01088163

8. Achidi AU, Ajayi OA, Maziya Dixon B, Bokanga M. The effect of processing on the nutrient content of cassava leaves J. Food. Process. Preserv 2008; 32: 486-502. http://dx.doi.org/10.1111/j.1745-4549.2007. 00165.x

9. Akintola AU, Grisson FE, Toramiro SE, Oke OL. Parameters of thyroid function in the edemic goiter. Nutr. Health 1998; 18: 355-367.

10. Onwuka. The tropical tuber crops, John Wiley and sons Ltd, New York; 1978. p. 86-87.

11. Lowry OH, Rosenbrough NJ, Farr AL, Randall RJ. Protein measurement with folin phenol reagent, J. Bio. Chem 1951; 193: 265-275.

12. Miller GL. Use of DNS for determination of reducing sugar, Analytical chemistry 1959; 31 suppl3: 426-428. http://dx.doi.org/10.1021 /ac60147a030

13. Suzanne N. Food analysis, Purdu University, West Lafayette, Indiana plenum publishers; 2003.

14. James CS. Analytical chemistry of foods, Chapman and hall publication New York; 1995.

15. AOAC, Methods of the association of official analysis, chemists, $15^{\text {th }} \mathrm{ed}$, Virginia.

16. Udoh EJ, Ogunwale JA. Laboratory manual for the analysis of soil, plant and water sample, $2^{\text {nd }}$ ed, London Macmillan publisher; 1986. p. 67-137.

17. Oke OL. Chemical studies on some Nigerian food stuffs. Latum. W. Afr J. Bio. Appl. Chem 1969; 18: 53-56.

18. Kakade ML, Simon NR, Liener TE. Biochemical and nutritional assessment of different varieties of soyabean, J. Agr. Food. Chem 1971; 20: 87-90. http://dx.doi.org/10.1021/jf60179a024

19. Markkar HPS, Blummer, Browy NK, Becker K. Gravimetric analysis of tannins and their correlation with chemical and protein precipitation methods, J. Sci. Food Agr 1993; 61: 161-165. http://dx.doi.org/10.1002 /jsfa.2740610205

20. W Leung. Food composition table for use in Africa, FAO; 2008

21. Fredrick DO, Hominy H. Soul food from Africa to America, Columbia University Press Chap 1-2.

Cite this article as:

S. Anbuselvi, T. Balamurugan. Nutritional and anti nutritional constituents of Manihot esculentus and Plecutranthus rotundifolius. Int. Res. J. Pharm. 2013; 4(9):97-99 http://dx.doi.org/10.7897/2230-8407.04919 